\title{
JUURNAL.RU
}

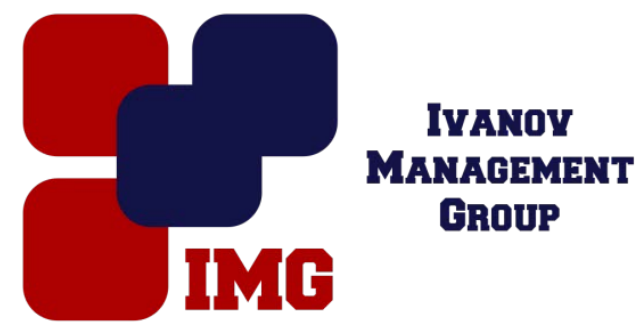

Сависько Ан. А. ФГБОУ ВО «Ростовский государственный медииинский университет» Минздрава России Ростов-на-Дону, Россия

doi: 10.18411/lj-30-11-2016-3-12

idsp 000001:lj-30-11-2016-3-12

\section{Особенности цитокинового баланса у детей с хроническим гнойным риносинуситом}

В структуре инфекционной патологии у детей раннего возраста лидирующую позицию занимают заболевания респираторного тракта. Наиболее часто регистрирующейся патологией верхних дыхательных путей являются риносинуситы, требующие госпитализации в детские ЛОР-отделения более чем в 50\% случаев [1,2]. При этом в настоящее время отмечается преобладание гнойной формы заболевания с тенденцией к нетипичному течению в виде склонности к затяжному, хроническому, часто рецидивирующему воспалению, устойчивому к антибактериальной терапии[3, 4]. Такой вариант течения заболевания чаще наблюдается у детей высокого инфекционного риска, в том числе, рожденных женщинами,перенесшими различные микробновоспалительные заболевания во время беременности $[5,6,7]$.Данные заболевания являются маркерами иммунной дисрегуляции, в основе которых лежат нарушения кинетики иммунного ответа $[8,9,10]$, что определяет особую актуальность изучения иммунопатогенеза бактериальных инфекций у детей и условий их хронизации [11].

Одним из перспективных направлений расшифровки механизмов противомикробной защиты является изучение показателейрегуляторных молекул - провоспалительных и противоваспалительных цитокинов, которые определяют не только направление, но выраженность и динамику иммунного ответа. [12, 13, 14].

Цель: установить особенности клинического течения заболевания и цитокиновой регуляции у детей раннего возраста с риносинуситом в зависимости от отягощенности их инфекционного анамнеза при рождении.

Материалы и методы. Обследовано 68 детей раннего возраста (средний возраст 2 года 9 мес) с различными вариантами течения риносинусита, из которых 37 человек были из группы высокого инфекционного риска, матери которых перенесли инфекционно-воспалительные заболевания органов дыхания 
с развитием бактериальных осложнений ЛОР органов во время беременности (1 группа) и 31 ребенок - с благоприятным инфекционным анамнезом при рождении (2 группа).Всем больным было выполнено полное клиниколабораторное обследование, включающее сбор жалоб и анамнеза, эндоскопию ЛОР органов и компьютерную томографию околоносовых пазух. Уровень цитокинов IL-1 $\beta, \quad$ IL-4, IL-6,IL-10, INF- $\alpha, \quad$ INF $\gamma$ определяли методом иммуноферментного анализа наборами реактивов ООО «Цитокин» (СанктПетербург). Контрольную группу составили 30 здоровых детей в возрасте 3 лет, не страдающих хроническими заболеваниями.

Полученные результаты и их обсуждение. Анализ анамнестических данных и особенностей клинического течения заболевания, позволил установить, что 1 группу в превалирующем большинстве $(84,6 \%)$ составили дети с хроническим, гнойным,часторецидивирующим течением риносинусита. В то время как во 2 группе пациентов, количество таких детей было достоверно ниже (34,7\%). Результаты исследования свидетельствовали о наличии цитокинового дисбаланса в 1 группе детей с высоким инфекционным риском при рождении, в отличие от детей 2 группы с благоприятным анамнезом. Так у детей 1 группы было установлено достоверное увеличение концентраций TNF- $\alpha-43 \pm 1,24$

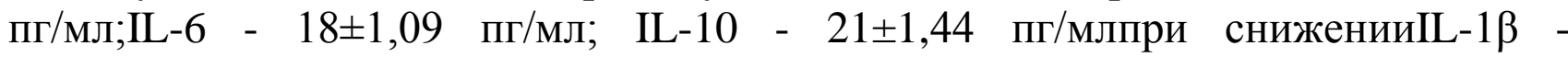

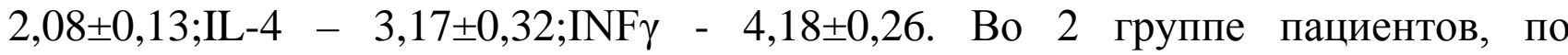
сравнению с детьми 1 и контрольной групп, достоверно были повышены

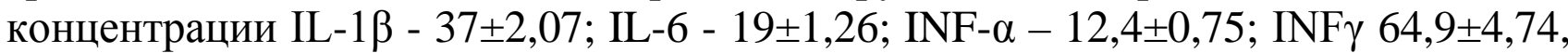
а изменений концентраций остальных исследуемых цитокинов достоверно не выявлено.

Таким образом, установлено наличие дисбаланса цитокиновой регуляции у детей с хроническим гнойным риносинуситом, рожденных с высоким инфекционным риском. Это, на наш взгляд, обусловливает в определенной степени, развитие микробно-воспалительного процесса у детей первых лет жизни с хроническим часто рецидивирующим течением.Определение данных иммунологических показателей позволит повысить прогностическую значимость течения инфекционной патологии верхних дыхательных путей у детей, а также определить объём лечебных и профилактических мероприятий. 


\section{Литература}

1. Волков А.Г., Гюсан А.О., Боджоков А.Р., Стагниева И.В.. Хохлачев С.М., Уз-денова Р.Х., Давыдова Л.С. Анализ орбитальных и внутричерепных осложне-ний синуситов по некоторым стационарам Северного Кавказа // Российская оториноларингология. 2008. №4. С. 57-61.

2. Волков А.Г., Стагниева И.В. Острый и хронический фронтит: современный взгляд проблему // Вестник оториноларингологии. 2012. №6. С.98-102.

3. Волков А.Г., Стагниева И.В. Головная боль в области лба с точки зрения ото-риноларинголога // Российская ринология. 2007. №4. С.29-34.

4. Волков А.Г., Стагниева И.В., Ерошенко А.Ю. Значимость локального болевого симптома при фронтитах в настоящее время // Вестник оториноларингологии. 2010. №4. С.38-40.

5. Костинов М.П., Мещерякова А.К., Фошина Е.П., Тарбаева Д.А., Сависько А.А., Зайцева Е.В. Клиническое течение острой респираторной инфекции и состояние микробиоценоза верхних дыхательных путей у беременных // Журнал микробиологии, эпидемиологии и иммунобиологии. 2012. № 5. С. 12-16.

6. Сависько А.А., Костинов М.П., Харсеева Г.Г., Ястребова Н.Е., Шмитько А.Д., Евдокимова Е.П., Иванова И.А., Трухачев А.Л., Лабушкина А.В., Черданцев А.П., Подгорный И.В. Состояние иммунитета к streptococcus pneumoniae у здо-ровых новорожденных детей // Педиатрия. Журнал им. Г.Н. Сперанского. 2015. Т. 94. № 1. С. 9-12.

7. Бойко Н.В., Бачурина А.С., Оксенюк О.С., Колмакова Т.С. Лечение послеопе-рационного воспаления после тонзиллэктомии у детей // Педиатрия. Журнал им. Г.Н. Сперанского. 2016. Т. 95. № 1. С. 93-96.

8. Бойко Н.В., Стагниева И.В. Дифференциальная диагностика лицевых болей //Российская ринология. 2012. Т.20. №4. С.39-41.

9. Кетлинский С.А., Симбирцев А.С. Цитокины. СПб: ООО «Издательство Фо-лиант», 2008. 552c.12.

10. Стагниева И.В., Симбирцев А.С. Роль цитокинов в патогенезе лицевой боли при риносинусите // Медицинская иммунология. 2015. Т.17. №S(спец.выпуск). С.319.

11. Стагниева И.В., Симбирцев А.С. Иммуномодулирующая терапия у больных риносинуситом с латентным течением // Медицинская иммунология. 2015. Т. 17. № S. С. 423.

12. Стагниева И.В., Симбирцев А.С., Волков А.Г. Роль факторов иммунной реак-тивности в патогенезе клинических проявлений риносинусита//FoliaOtorhinolaryngologiaeetPathologiaeRespiratoriae. 2016. T. 22. № 2. C. 4-11. 
13. Стагниева И.В., Симбирцев А.С. Значение цитокинового профиля в проявле-нии болевого симптома при риносинусите // Цитокины и воспаление. 2015. Т.14. №4. С. 29-34.

14. Бойко Н.В., Бачурина А.С., Жданов А.И. Профилактика послеоперационных кровотечений при аденотомии // Российская ринология. 2015. Т. 23. № 2. С. 26-30. 